\title{
Archetypal Theme of Ambivalent Identity in Le Anne Howe's Moccasins Don't Have High Heels and The Red Wars
}

\author{
Hussein H. Zeidanin \\ Department of English Language and Literature, Tafila Technical University, Jordan
}

\begin{abstract}
The current study examines archetypal patterns and themes underlying contemporary Native American initiation fiction. Moccasins Don't Have High Heels and The Red Wars, both written by Le Anne Howe, are informed by the conventions of initiation fiction. The portrayal of characters with uncertain identities and feelings of alienation and solitude is a recurring theme in both works which are approached from the viewpoint of archetypal criticism. The research claims, questions and aims are stated in the introduction, which also offers an overview of Native American literature, initiation fiction, and archetypal criticism. An archetypal reading of Howe's stories is presented in the Discussion. Research findings and analysis outcomes are stated in the Conclusion.
\end{abstract}

Index Words-ambivalence, archetypal criticism, initiation fiction, Le Anne Howe

\section{INTRODUCTION}

The initiation story, which is defined as a protagonist's journey from ignorance of the outer world to vital knowledge, or as a profound self-discovery that leads to a significant life or social change, is an archetypal theme in contemporary Native American writing. It depicts a significant shift in the protagonist's knowledge of the world or himself, or a change in character, or both, and this transformation must direct or lead him towards an adult world (Marcus 1960). Native American initiation fiction often features an estranged protagonist, who finds himself trapped between two worlds or ambivalent cultures as he seeks a meaningful identity. The ongoing identity crisis and ensuing sense of alienation he undergoes cannot be resolved or entirely avoided. The protagonist, a fringe person who lives on the outskirts of his ancestral culture, recognizes that the old way of life is vanishing. He simultaneously finds mainstream society repulsive for its role in the dispossession and extermination of American Indians. At best, he is content with his lot in life, and at worst, he dies. The purpose of this research paper is to delve into Anne L. Howe's autobiographical short stories Moccasins Don't Have High Heels (1991) and The Red Wars (1991) that are based on her experiences as a bond saleswoman and as a student, respectively. The underlying initiation patterns and themes in both stories will be defined and analyzed. The key question raised is whether protagonists and first person narrators in Howe's works are typical initiation figures. The approach used to study the stories' recurring patterns and themes is archetypal criticism.

\section{A. Overview of Native American Literature}

The term Native American literature has been a source of debate for decades. It was first used to describe non-Indian works about America's indigenous peoples. Retelling Indian ceremonies, legends, and performances by Puritan writers gave rise to the legendary and conventional images of the American Indian as a noble savage, dying warrior, stoic hero, enigmatic stranger, or comic drunk that persist today (Murray, 1985, p.158). Later, the term signified Indian literary works that were written in English. The writers attended schools run by Christian missionaries, and began to speak and write in English. They used classic literary forms like novels, poetry, and memoirs to preserve their stories, experiences, and myths. Symbolism and mythology abound in Native American works, which continue to use the oral tradition, incorporating narrative elements such as song or repetition. The tales, myths, legends, and stories, which arose from the oral tradition, can be classified based on their closeness in meaning and intent into the following categories:

1) Hero Initiation: A young man, who goes through ritual initiation and subsequently does a heroic act, is a common trope in Native American literature. He does not really belong to either his original tribe or the European settlement world; therefore he will have to prove himself with some bold feat. In the end, the hero usually dies tragically and is idolized by his tribe.

2) Trickster: The trickster is a prevalent motif as well. He could be a bumbling character that exposes human greed. The trickster is frequently punished as a result of his selfish or malicious conduct. Though he may cause harm to others or act inappropriately, he is viewed as a cultural hero in tribal traditions.

3) Mythology: The attribution of human characteristics such as avarice and envy to inanimate objects and animals is another recurring theme in Native American literature (Thamaran, 2015).

Native Americans produced protest writing in the late $18^{\text {th }}$ and early $19^{\text {th }}$ centuries to resist the efforts exerted to eradicate indigenous civilizations and cultures. In this early historical and literary struggle of Native Americans, it is 
also vital to mention the Pan-Indian movement, which advocated the belief that the land would be returned to Native Americans through divine intervention (Hertzberg, 1981). In the late $19^{\text {th }}$ century, a series of historical events such as the American Civil War led to the integration of Indians into white American society, spurring the publication of several novels about assimilation as a survival strategy like Wynema: A Child of the Forest (1891) by Alice Callahan, Queen of the Woods (1899) by Simon Pokagon and Sundown (1934) by John Joseph Matthews. Modern pan-Indianism in the early $20^{\text {th }}$ century, unlike prophetic and messianic groups in the $18^{\text {th }}$ and $19^{\text {th }}$ centuries, was not concerned with returning to or restoring Native cultural homelands. Instead, modern Pan-Indianism demanded Native Americans to assimilate the white-dominated culture (Hertzberg, 1981). Between 1920 and 1940, Native American novelists delved deeper into the issue of assimilation. Indian protagonists in their works renounce indigenous roots and adapt into white civilization.

During World War II, which lasted from 1939 to 1945, many Native Americans joined the US armed forces to defend their country. The participation of American Indians in US military conflicts changed indigenous perspectives of Native life, culture, and customs while also kindling Indian patriotism toward the United States. As a result, following the war, many Native Americans left the reservation and became Americanized, with assimilation appearing to be a necessary adaptation for success (Pérez, 2019).

Since the 1960s, however, Native American writing has shifted away from assimilation and toward rejection of white dominant society's traditions and norms (Pérez, 2019). This mindset was mirrored in Native American renaissance writing, such as House Made of Dawn (1968) by N. Scott Momaday and Ceremony (1977) by Leslie Marmon Silko, which aimed to reclaim and preserve traditional indigenous values while adapting to contemporary Western influences. The importance of family, preservation of indigenous culture, and uniqueness of the Native American experience as reflected through family bonds and love relations are other archetypal themes explored in James Welch's Winter in the Blood (1974), N. Scott Momaday's The Way to Rainy Mountain (1969) and Louis Erdrich's Love Medicine (1984). Characters' sentiments of alienation and ambivalence in renaissance literature usually arise from internal conflicts rather than from encounters between Indians and non-Indians (Murray, 1985).

Bildungsroman themes also recur in renaissance works like Momaday's House Made of Dawn (1968) and Deloria's Waterlily (1988). Bildungsroman genre connects Native Americans to plants and animals, rivers and rocks, and everything else that was considered important in the life of America's indigenous inhabitants. Indian people are believed to be tied to the land and its life through a spiritual kinship with their living and deceased relatives. Coyote, raven, fox, hawk, turtle, rabbit, and other animal characters in the folklore are considered kinfolk by many Native Americans. In the same way, the Plant People are linked to Indians. Oak, maple, pine, cedar, fir, corn, squash, berries, and roots are all relatives (Thamarana, 2015).

\section{B. Theoretical Background}

The term archetype refers to narrative patterns, character types, themes, and images that recur in a wide range of literary works, as well as myths, dreams, and even societal rituals. The origins of archetypal criticism can be traced back to psychologist Carl Jung, who proposed that humanity possesses a collective unconscious, a form of common psyche or fantasy that manifests itself in dreams and myths and contains themes and imageries that we all share (Dobson, 2005). Northrop Frye, a Canadian literary critic and theorist, was instrumental in broadening the notion of archetype to encompass literary contexts.

Archetypal literary criticism is a method of evaluating a work by focusing on its recurring myths, symbols, imagery, and character types. It asserts that a text's meaning is shaped by archetypes. Identifiable character types such as the trickster or hero, symbols such as the apple or snake, or imageries such as the crucifixion are all examples of archetypes (Garry \& El-Shamy, 2005).

In archetypal criticism, formalist approaches are utilized to probe deeply into literary texts in search of recurrent underlying patterns. New Criticism, archetypal critics believe, is overly reductive in its disregard for intertextual components and detachment of the text from contexts. Meaning, from an archetypal viewpoint, cannot be found merely on the pages of a work, nor can the work itself be regarded a separate entity; rather, it is in archetypal images and patterns.

\section{DISCUSSION}

The typical initiation figures in Howe's Moccasins and The Red Wars are the nameless female protagonists and firstperson narrators who, at first, appear to be entirely entrenched in the American culture with little awareness of their Native American ancestry. In Moccasins, the narrator sounds well-versed in the bond industry, which is emblematic of American capitalism. She has spent the last five years working for a bond company in Dallas, Texas. She leaves the bond business only after the 1987 stock market crash, dubbed Black Monday. Years before the crash, she considered stopping bidding, but she never did, revealing that she enjoyed it. When the Dallas Office is shut down, she will be the last one to turn out the lights and leave. Her yearning for bidding over the next few months finds an expression in her fantasies that she is back in the bond business.

In The Red Wars, the narrator's behavior, language and way of life tell that she is an American. She studies law at Oklahoma State University, and works part-time as a receptionist for the American Civil Liberties Union (ACLU). 
Then she drifts into journalism and works for the Dallas Morning News. Her ability to type and write professionally has contributed to her success as a journalist. Most notably, her color and attire are more indicative of her Whiteness than her Native American heritage. This explains why some Native Americans, such as Thunderhawks, have a hard time recognizing her as a Choctaw woman. She appears to have no knowledge of indigenous languages, ceremonies, or customs. When California Red Wing, a medicine man and chain smoker of Cherokee origin, holds a ceremony for burying the skull of an anonymous Indian, the narrator admits she neither grasps the ritualistic worth of the sage bundle nor the language used in the ceremony.

The narrator as well shows no concern about the plight of American Indians. She refuses to join the American Indian Movement (AIM) or Indian non-profit organizations that sought to build a better future for Indians. She would rather stay at home with her two children and finish her education than campaign for the Indian cause. She focuses solely on her own family obligations and personal aspirations, and nothing else. Hence, when informed about the murder of a seventeen-year-old Indian girl, she strangely remains apathetic and says and does nothing.

However, protagonists in Moccasins and The Red Wars demonstrate ambivalent belonging, resulting from travelling between domains of different cultures as well as integration with Indian diasporas. In Moccasins, the narrator and her close friend Carla take a driving tour of Wyoming and the Wild West to get away from the repercussions of the 1987 stock market crash. The tour coupled with the forced unemployment revitalizes her indigenous sense of place-time continuum. Native American tribes employed the six-directional grid, which includes East, West, South, North, Up, and Down, to pinpoint the present or historical boundaries of their homelands. The term "home" has a considerably broader sense for Native Americans than it does for non-indigenous Americans. Though the majority of Native Americans have been displaced, the memory of the traditional habitation or homeland lives on. Native Americans consider their homelands as something they belong to rather than something they own; other peoples, those unlike themselves, are also created for their own places (Cordova, 2002).

One implication of the spatial continuum that the narrator repeatedly refers to is that Americans are alien to America, which was carved out to be Native Americans' homeland. She believes that Americans belong somewhere else, and that colonial invasions have failed miserably in their attempts to expel Native Americans from their ancient homelands and eradicate their indigenous civilizations once and for all, "it seems it was not enough that the aliens wanted to capture our souls for a once-a-week alien God, they wanted to own our physical bodies" (Howe, 1991a,365).

The diverse indigenous languages, artifacts, customs, rituals and ceremonies are tied with certain territories. Native Americans tend to identify each other as Cherokee, Choctaw, Navajo or Dakota based on certain territorial identifiers. Moccasins, for instance, are territorialized artifacts traditionally worn by Choctaw women within their homeland's boundaries. Wearing moccasins beyond that bounded space, the narrator believes, is a form of deterritorialization. Thus, she never puts them on while in mainstream society; she will only replace her high-heeled American shoes with the hoarded pair of moccasins when she goes homeward.

The Native American temporal continuum, which the narrator metaphorically imagines as a chair whirling around and around until it eventually sits still, departs from the western linear progressive concept of history, with subsequent events superseding earlier ones. Historical occurrences based on the western conception are limited in scope, single, and isolated. However, the Native Americans' cyclical notion of time implies that there is no such thing as a human event in and of itself. Instead, a defining event in history can be attributed to the sum total of minor events that preceded it, or to how subsequent events continue to reflect its cause and significance (Jojola, 2002). Accordingly, Native America's history of colonization, displacement, and dispossession is not viewed as a sequence of isolated occurrences. Rather, it is a series of interconnected events that can be comprehended only when a question that starts with why instead of what is asked. The cause of an occurrence is far more significant than the occurrence itself to Native Americans.

The narrator projects her cyclical notion of time onto the present so as to understand why occurrences happen and how they are interconnected. She, for example, connects clear-cutting national forests and contamination of natural resources with the white man's unceasing attempts to wipe out Native American reservations, "the grass ain't green, the sky ain't blue, and the rivers are full of trash. We didn't want to leave this place - this time, space continuum thing to you - but you wanted it. You got it. Now fix it!" (Howe, 1991a, 366). That destruction has led to the extermination of indigenous cultures and relocation of Native Americans.

Other minor occurrences, such as South Dakota archaeological conference, have a similar impact upon the Indians. The conference manifests the destructive role American schools and research centers played in distorting indigenous cultures and histories, and in objectifying Native Americans as artifacts or commodities to be studied. The narrator cites archaeologists who assert "Indians had small gene pools so we must have practiced incest", "Did you know that Indian women are very jealous of their men?" (Howe, 1991a, 364) and "Indians don't talk much, but when we say something it's always profound and fraught with meaning" (Howe, 1991a, p.364). She cites others talking about what diseases got to the Indians, and how the Indians felt about the time-space continuum. Very few archaeologists and writers, like Edward Galeano, acknowledged Indians as civilized humans rather than objects of study, and opposed the historical denial of Native Americans "as subjects of history. Indians have folklore, not culture, they practice superstitions, not religion, they speak dialects, not languages, they make crafts not arts" (Howe, 1991a, p.365).

Another minor occurrence is the discovery of the bodies of an Indian woman and her child buried amid the bodies of twenty-six white people in a cemetery unearthed in Iowa in 1971. While the whites' bodies were reburied, the Indian 
and her child were placed into a box and shipped to Iowa City to be studied. This incident, the narrator asserts, confirms the exclusive and discriminatory practices against Indians, both in death and in life.

In The Red Wars, relationships with individual Indians belonging to different tribes and diasporic communities revive the narrator's indigenous identity. Her connection with Indian activists, in particular, in Texas exposes her to a wide range of political and intellectual movements in modern Native America, each with its own set of beliefs and ideologies. She learns about AIM through Thunderhawk. It is a separatist movement fighting for the establishment of an Indian Nation on a portion carved out of New Mexico. Norway will back the new nation, which will be home to all Indians, in gaining a seat in the United Nations. Machine guns and weapons, Thunderhawks discloses, are being stashed in the desert for that purpose.

The narrator also learns about two non-profit organizations in Dallas through California Red Wing. Both are competing for grant money, and claim to be Texas' only Indian non-profit organization. Neither fosters separatist or dissident sentiments. Instead, they advocate for cultural assimilation and integration in order to secure financial support from the US government.

The narrator compares Jim-Jack, a Cherokee house builder and self-made guy from West Columbia, Texas, who refuses to join any American Indian movement, to a "Regan man" or "Ross O. Swimmer" (Howe, 1991b, p.370). Jim feels embarrassed and ashamed that Indians, including his grandparents, get welfare from the American government. He believes Indians can reclaim their pride only by learning to thrive without government support. Thus, reservations should be obliterated and Indians should be liberated. He is a supporter of American Indian museums which, in his belief, contribute to the preservation of American Indian heritage.

At the end of Moccasins and The Red Wars, neither protagonist manages to resolve or overcome the cultural contradictions characterizing her identity. Instead, they become far more alienated and ambivalent than before. In Moccasins, the narrator does neither cross into the bounded realm of her indigenous culture, nor does she situate herself in American society. Rather, she straddles the line between Indian and American, not entirely identifying as either. She eventually recognizes America's ethnic and cultural diversity, 'because, my country (this is my country) tis' of me, tis of thee. First. Last. And Forever. Am I getting to you, somehow? I will get to you. Somehow. Because, together, man, woman, child, all that exists, Together, we can GET IT Together" (Howe, 1991a, p.366). This recognition signifies a departure from her former essentialist and separatist convictions. She now feels that all Americans, regardless of race or culture, belong in America. Therefore, she emphasizes that the ideals of diversity, coexistence, and tolerance that have made the United States great should prevail and be reaffirmed.

The narrator of The Red Wars likewise condemns the separatist and assimilationist views disseminated by Native American activists and intellectual movements in diaspora. On the one hand, she criticizes the tendency of Indian nationalists to build a nation for Indians. She, too, resists Indian assimilationists' demands for complete immersion in American culture. Native American culture will be shredded in the melting pot, she argues, if reservations are demolished and Indians are integrated into larger American society. She further explains that forcing Indians to live in the past and conserving indigenous artifacts in museums rather than putting them to use would be detrimental to the survival of Native American civilizations. On this account, she receives Jim-Jack's assimilationist viewpoints with outrage and hostility, "Rage. Rage. Rage. I will castrate this man, this cultural eunuch, with my hands, with my head, with my body. I will emasculate him in the name of Red Rights ... Red earth ... my Indian grandmother" (Howe, 1991b, 370).

The narrator seems to be torn between opposing viewpoints and cultures as if she were at a fork in the road. She can only take one road at a time. Yet, she never sets foot on any. Thunderhawk's "scent" (Howe, 1991b, p.367), with which she was enticed, touched, and consumed, draws her back to the indigenous past. The narrator's children, education and work, however, bring her back to the current borderline identity that exacerbates her solitude, ambivalence and estrangement.

\section{CONCLUSIONS}

The initiation story is a staple of contemporary Native American literature. It entails a profound self-discovery or a dramatic change in the protagonist's identity and viewpoints. Native American initiation literature typically depicts an estranged character who, after living alone in dominant society, returns to the reservation and finds himself stranded between two worlds or civilizations. The characters in Howe's works have qualities that are typical of initiation figures, such as ambivalent belonging and estrangement. The heterogeneity of the cultures the protagonists are exposed to and influenced by gives rise to borderline identities that belong nowhere and are marked with contradictions and uncertainties. The paper maintains that travelling back and forth between domains of different cultures, such as the white-dominated society, Indian diasporas and reservations, creates a liminal area where disparities and contradictions are unbridgeable and unresolvable. Neither protagonist, in both tales, manages to homogenize the inconsistencies defining her identity and culture.

\section{REFERENCES}

[1] Cordova, V. F. (2002). Bounded Space: The Four Directions. APA Newsletter. 2.1, 3 - 6. 
[2] Dobson, D. (2005). Archetypal Literary Theory in the Postmodern Era, Journal of Jungian Scholarly Studies, 1.1, 1 - 16.

[3] Garry, J. \& El-Shamy, M. H. (2005). Archetypes and Motifs in Folklore and Literature: A Handbook. Armonk, NY: M.E. Sharpe.

[4] Hertzberg, B. H. (1981). The Search for an American Indian Identity: Modern Pan-Indian Movements, Syracuse NY: Syracuse University Press.

[5] Howe L. A. (1991a). Moccasins Don’t Have High Heels. In American Indian Literature: An Anthology, Alan R. Velie (ed.), Norman: University of Oklahoma Press, $361-366$.

[6] Howe L. A. (1991b).The Red War. In American Indian Literature: An Anthology, Alan R. Velie (ed.), Norman: University of Oklahoma Press, $367-370$.

[7] Jojola, T. (2002). Toward a Cyclical Model of Indigenous History. APA Newsletter. 2.1, 6 - 9.

[8] Marcus, M. (1960). What Is an Initiation Story? The Journal of Aesthetics and Art Criticism, 19.2, 221-228.

[9] Murray, K. J. (1985). What is Native American Literature? Canadian Journal of Native Studies, 2.1, 151-166.

[10] Pérez, L. S. (2019). A Concise Overview of Native American Written Literature: Early Beginnings to 1968 International Journal of Languages, Literature and Linguistics, 5.3, 176 - 185.

[11] Thamarana, S. (2015). Origin and Development of Bildungsroman Novel in English Literature. International Journal of English Language, Literature and Humanities, 3.6, 21-26.

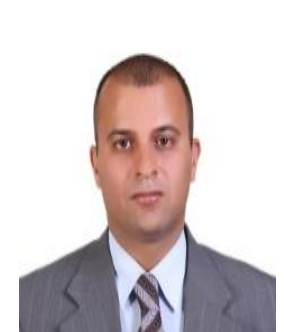

Hussein H. Zeidanin was born in Bosira, Jordan, in 1979. Zeidanin earned a bachelor's degree in English language and literature from the United Arab Emirates University in 2001, a master's degree in translation from Yarmouk University in Jordan in 2005, and a doctorate of philosophy from Indiana University of Pennsylvania in the United States in 2011.

$\mathrm{He}$ is an experienced translator and professor. He is currently employed at Tafila Technical University, Jordan, as an associate professor of English. He served as a lecturer at Taibah University in Saudi Arabia from 2019 to 2020. He taught at Al-Buraimi University College in Oman from 2006 to 2007. He also worked as a translator for several language and translation centers in the United Arab Emirates and Jordan. His research interests include literary criticism, $20^{\text {th }}$ century American fiction, comparative literature, feminist and postcolonial literature, and translation studies. 